\title{
Effect of environmental gradients on leaf morphological traits in the Fandoghlo forest region (NW Iran)
}

\author{
Roghayeh Jahdi ${ }^{(1)}$, \\ Mahdi Arabi ${ }^{(2)}$, \\ Filippo Bussotti ${ }^{(3)}$
}

\begin{abstract}
The purpose of this study was to analyze the effects of altitude, the position of the trees along a gradient of canopy cover, and the orientation of their crown on leaf traits of 18 deciduous woody species belonging to 10 families in the Fandoglo forest region in Ardabil, North West of Iran. We measured eight leaf traits (leaf width, length, area, thickness, water content, leaf mass per area, specific leaf area, and dry matter concentration) of trees sampled at sites subjected to different light regimes (forest edge, forest understory, and isolated trees). All traits were measured on more than 3600 leaves from 90 trees sampled in two altitudinal ranges (low: 1300-1500 m a.s.l.; high: 1500$1700 \mathrm{~m}$ a.s.l.). A two-way ANOVA and $t$-test for independent samples were applied to test for differences in leaf traits between different altitudes and degree of canopy cover. The results confirmed that species' leaf traits were more strongly correlated with the altitude and canopy cover rather than the orientation of the crown. No relationship between leaf traits and crown orientation was detected. All leaf traits had significantly higher values at low than at high elevation, indicating that environmental factors such as atmospheric $\mathrm{CO}_{2}$ concentration, temperature, light, irradiance, and wind deeply impact on foliar morphology and function; however, water content and specific leaf area showed an opposite trend. Also, species with different positions along the gradient of canopy cover could have different responses to elevation. Our results indicate that the variation of functional (morphological and physiological) traits in different tree species are affected by altitude and light regime. This might provide a theoretical basis for afforestation and forest management activities in the Fandoghlo forest region.
\end{abstract}

Keywords: Leaf Morphological Traits, Fandoglo Forest Region, Altitude, Tree Position, Crown Orientation

organ most directly affected by the environment and display a series of attributes linked to specific functions and responses to biotic and abiotic stress factors. These attributes may be subdivided into: (i) morphological traits; (ii) chemical traits; (iii) physiological traits; and (iv) symptoms (Hansen et al. 2004, Bussotti \& Pollastrini 2015). Leaf morphology is incredibly variable both among and within species (Hovenden \& Vander Schoor 2006). Leaf morphological traits of most woody plants change with the local environmental conditions as a response to change in abiotic factors like soil moisture (Kolodziejek \& Michlewska 2015), air temperature (Holland \& Richardson 2009), solar radiation (Bussotti et al. 1998), and atmospheric $\mathrm{CO}_{2}$ concentration (Thinh et al. 2018). Understanding the adaptive modifications of leaf traits to changes in environmental conditions, e.g., along elevation gradients, is vital (Akinlabi et al. 2014). Altitudinal variation involves changes in many environmental factors, such as air temperature, humidity, heat and sunlight radiations, soil depth, and wind speed (Soethe et al. 2008, Xu et al. 2017). Temperature decreases, while precipitation and radiation increase with increasing altitude (Li et al. 2018, Wang et al.
2018). The orientation of tree crown according to the cardinal points can also have a complex impact on climatic parameters by modifying temperature and light conditions, which also influence leaf morphology and physiology (Bodor et al. 2014). For example, south exposed leaves are subject to higher light radiation and harsher drought conditions than leaves exposed northwards. Furthermore, forest canopy features might be one of the most predominant determinants of tree species distributions, especially in mountain environments (Li et al. 2014). Forest canopy characteristics (in terms of composition and density) affect the patterns of resource availability (i.e., light, water, soil nutrients) on the forest floor, which in turn influence the foliar morphology (Wang et al. 2012).

Numerous studies focused on the acclimation of leaves, through leaf traits analysis, to environmental changes on species and community level. According to Bussotti et al. (1998), individual leaf surface decreases under drought conditions, while the thickness of leaves and their specific dry weight increases. The analysis of morphological characteristics of leaves of Dodonaea viscosa subsp. angustissima (DC.) J. G. West in South Australia indicated that 
leaf width is linked to regional maximum temperature (latitude gradient) and leaf area to local minimum temperature (altitude gradient - Guerin et al. 2012). Akinlabi et al. (2014) revealed that plants generally respond to changes in altitudinal gradient, showing a reduction of dimensions at higher altitudes. Researchers also reported that high light and low altitudes are limiting factors for growth in bamboo ( $\mathrm{Li}$ et al. 2014). De la Riva et al. (2016) observed that species with high leaf mass per area (LMA) and leaf density (LD) could be found in habitats with low water availability. Studies carried out in temperate and subtropical forests showed that dry matter content (DMC) was highest in trees, followed by shrubs and herbs (Liu et al. 2019). Higher DMC increases the resistance of gas diffusion in leaves (England \& Attiwill 2006).

Several studies in forest stands along environmental gradients have been previously carried out in the Hyrcanian forest of Northern Iran. For example, Yousefzadeh et al. (2010) studied the variation in leaf characters of Parrotia persica (DC.) C.A. Mey. as a consequence of their position in the canopy along an altitudinal gradient. These authors observed a significant increase in few leaf features (width of lamina, base angle, number of pair vein of leaf, top and end of leaf figure) with increasing altitude. The results of the studies carried out on the effects of altitude on leaf morphology of Caucasian alder (Alnus subcordata C. A. Mey) showed a substantial reduction in lamina length with elevation (Akbarian et al. 2011). A study of the variability in leaf morphology of three chestnuts (Castanea sativa Mill.) natural populations using principal components analysis (PCA) showed that most of the variation (85\%) was explained by the first four components; leaf size emerged as the most important variable in the corresponding eigenvectors (Zarafshar et al. 2010). Paridari et al. (2013) investigated the altitudinal variation of Carpinus betulus L. using leaf morphological traits, showing that altitude, and related temperature and rainfall, represent an essential driving factor of leaf morphological variation. Mohebbi Bijarpas et al. (2019a) focused on changes in leaf morphological characteristics of oriental beech (Fagus orientalis Lipsky) along altitudinal gradients; leaf length, leaf area index, and specific dry weight decreased significantly with increasing altitude, while the opposite was true for petiole length, petiole index, BW, leaf area, SLA, and relative water content. The results of Mohebbi Bijarpas et al. (2019b) also showed that leaf area, SLA, and relative water content of samples collected from two opposite parts of crowns (southern and northern exposures) in oriental beech increased with increasing elevation and decreased from 1200 to $1700 \mathrm{~m}$ a.s.l. The effects of climatic variations on some leaf morphological traits of Crataegus meyeri Pojark. were studied by Hamzehee et al. (2018); statistical analysis of climatic data and morphological traits showed that wind and temperature were the most influential factors affecting various morphological traits.

According to the above studies, leaf morphological traits in forest trees are affected by altitude (or temperature), water availability, light radiations, soil fertility, and topography. Despite the essential role of altitude in controlling the energy and mass exchange characteristics of terrestrial vegetation such as photosynthesis, respiration, transpiration, carbon and nutrient cycle, and rainfall interceptions, not much is known about the spatial variation in leaf morphology traits of Hyrcanian forests at a landscape scale. The most apparent general trend is a decrease in plant height with increasing altitude (Begon et al. 1990). The position of trees along a gradient of forest canopy cover and orientation of their crowns, which have been considered for their possible effects on leaf traits besides altitude, has not been investigated in detail in the forests until now. In this study, we attempt to establish relationships between leaf attributes and environmental condi- tions at a landscape level. Our specific goal was to investigate the effects of altitude, the position of trees along a gradient of canopy cover, and orientation of the crown on leaf traits in a broadleaved forest of the Fandoghlo region in Ardabil province (NW Iran), with the aim of better clarifying the role of environmental variables in the foliar morphology and physiology of species. These characteristics can be utilized as a monitoring tool to fulfill the following goals: (i) to predict plant performance under changing environmental conditions; (ii) to detect plant responses promptly after performing the treatment; (iii) to discover the main factors that can cause changes in the plant condition and composition; and (iv) to predict short-term growth response and long-term forest development.

\section{Material and methods}

\section{Study area}

The Fandoghlo forest region is part of Namin municipality, Ardabil, NW Iran, located between latitude $38^{\circ} 09^{\prime} 82^{\prime \prime}$ to $38^{\circ}$ $28^{\prime} 59^{\prime \prime} \mathrm{N}$ and longitude $48^{\circ} 29^{\prime} 27^{\prime \prime}$ to $48^{\circ}$ $42^{\prime} 36^{\prime \prime} \mathrm{E}$, with elevation ranging from 1320 to $2320 \mathrm{~m}$ a.s.l. (Fig. 1, Tab. 1). It borders Azerbaijan on western and northeastern sides and the Guilan province of Iran to the east. The area is influenced by the Caspian Sea on the one hand and by the mountainous climate of Sabalan on the other hand. Most of the rainfall occurs from June to September and snowfall is common in winter (November to March). The average annual rate of precipitation is $430 \mathrm{~mm}$ (20082018 ) at the Namin weather station (1480 $\mathrm{m}$ a.s.l.), with maximum monthly rainfall in October $(50 \mathrm{~mm})$ and no rainfall in August. The mean average temperature is $10{ }^{\circ} \mathrm{C}$. Monthly mean minimum and maximum temperatures are $-3.9{ }^{\circ} \mathrm{C}$ (January) and 35 ${ }^{\circ} \mathrm{C}$ (August), respectively. Soils are predominantly calcareous brown forest soils, and the organic matter content is moderate. Fandoghlo covers 18,034 ha, of which $41.6 \%$ is agricultural lands, $35 \%$ pastures, $11.7 \%$ for-

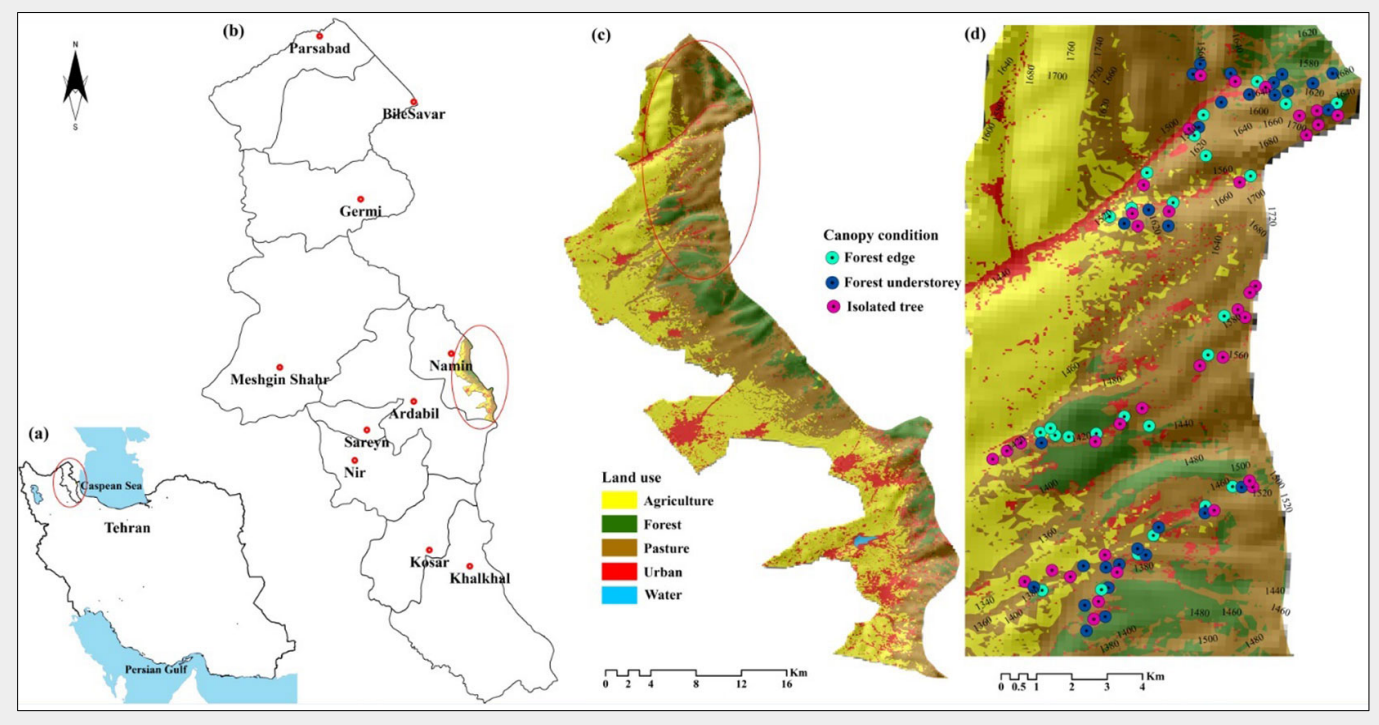

Fig. 1 - (a) Location of Ardabi province in NW Iran; (b) the Fandoghlo region in eastern Ardabil province; (c) land use map of the region; (d) the study area in the north part of Fandoghlo region, with indication of the sampled trees and their elevation (in $\mathrm{m}$ a.s.l.). Spot colors refer to the different positions of the sampled trees along a gradient of canopy cover (i.e., forest understory, forest edge, and isolated trees). 
ests, and $11.5 \%$ urban areas (Fig. 1). Concerning floristic characteristics, the Fandoghlo region can be divided in two parts: forest area and pasture area. Most species in the study area belong to the Euro-Siberian (Hyrcanian) and Irano-Turanean regions (Teimoorzadeh et al. 2015). The deciduous forests is composed by coppice ( $99 \%$ of the area) and high forest ( $1 \%$ - Yousefpour et al. 2005).

\section{Study design and sampling}

Two altitudinal zones were investigated, referring to here as "low" (1300-1500 m a.s.l.) and "high" (1500-1700 m). At both altitudes, leaves were collected from trees in the following three positions along a gradient of canopy cover (Tab. 2): forest edge (FE), forest understory (FU), and isolated trees (IT). The canopy characteristics at each sampling point were recorded and are summarized in Tab. 2. Sampling at the forest edge (FE) included broadleaved trees and shrubs such as Corylus avellana L., Quercus castaneaefolia C.A.Mey., Quercus macranthera Fisch.\& C.A.May., Fraxinus excelsior L., Acer campestre L., Mespilus germanica L., and Cornus mas L. Sampling in the forest understory (FU) included the same woody species and others such as Carpinus betulus, Crataegus meyeri, Crataegus microphylla Koch., Malus orientalis Uglitzk, Punica granatum L., Prunus divaricata Ledeb., with canopy cover ranging from $50 \%$ to $90 \%$ (Tab. 2). Isolated trees (IT) were sampled in open areas, where trees are typically sparse. There were significant differences between the sites where trees were sampled in terms of light intensity and water availability, because of the crown position and crown exposure to light. The age of trees was assessed using increment cores taken at breast height from at least five trees per site. Sampled trees were approximately 80 years old and more than $8 \mathrm{~m}$ tall, on average. Trees were randomly chosen within an area of 200 ha at low altitude and 500 ha at high altitude, with an average distance between trees of about $0.2 \mathrm{~km}$ (Fig. 1d).

Overall, ten different families of trees were sampled. More than 3600 leaves were randomly collected from four to ten trees for each species, totaling 90 trees. The detailed information on families, spe- cies and trees sampled are listed in Tab. 3. Pérez-Harguindeguy et al. (2013) recommended sampling at the peak of the growing season when leaves are fully expanded. At each site, forty mature and healthy leaves were collected on sunny days during the leaf-expansion season (July 2019). All leaves were taken from the upper outer part of the crown, completely sunny exposed, from four orientations (ten leaves for each north, south, east, and west exposures) at the same height (1.5-2 $\mathrm{m}$ above the ground). The detached leaves were carefully pressed between damp paper towels, sealed in marked plastic bags and preserved at $4{ }^{\circ} \mathrm{C}$, and then carried to the laboratory for further analysis.

\section{Morphology measurements}

The full list of morphological traits measured on sampled leaves is reported in Tab. S1 (Supplementary material). Leaf size parameters (leaf width: LW; leaf length: LL; leaf area: LA; leaf thickness: LT; fresh weight: FW; saturated weight: SW; dry weight: DW) are critical ecological indicators per se, since many stress factors reduce the productivity and growth of the whole plant and individual organs (Bussotti \& Pollastrini 2015). LW (maximum width of the blade), LL (base of petiole to leaf tip), and LT (at the central part of the lamina, half-way between midrib and margin) were all measured using digital vernier calipers with $0.1 \mathrm{~mm}$ resolution. The fresh leaves were scanned at $300 \mathrm{dpi}$ resolution, and the leaf area was determined by digital analysis of the images using the software Image-Pro Plus ${ }^{\circledR}$ v. 4.5 (Media Cybernetic Inc., Rockville, MD, USA). After measuring the LA, the leaf lamina was blotted dry with tissue paper to remove any surface water and immediately weighed to determine the saturated weight (SW). Leaf dry weight (DW) was determined after ovendrying at $70{ }^{\circ} \mathrm{C}$ for $72 \mathrm{~h}$. Water content (WC) was calculated based on the ratios between FW, SW, and DW, as indicated in Tab. S1 (Supplementary material). Based on leaf size parameters and the measured weights, leaf mass per area (LMA), specific leaf area (SLA), and dry matter concentration (DMC) were calculated. LMA ( $\left.\mathrm{mg} \mathrm{cm}^{-2}\right)$ is defined as the ratio between leaf mass (expressed as DW) and leaf area. SLA ( $\mathrm{cm}^{2}$
Tab. 1 - Characteristics of the study area.

\begin{tabular}{ll}
\hline Characteristics & Value \\
\hline Latitude N & $38^{\circ} 09^{\prime} 82^{\prime \prime}$ \\
& $38^{\circ} 28^{\prime} 59^{\prime \prime}$ \\
\hline Longitude E & $48^{\circ} 29^{\prime} 27^{\prime \prime}$ \\
& $48^{\circ} 42^{\prime} 36^{\prime \prime}$ \\
\hline Area (ha) & 18,034 \\
\hline Elevation (m a.s.l.) & $1320-2320$ \\
\hline Mean slope (\%) & 43 \\
\hline Soil type & Brown forest \\
\hline Mean annual temp $\left({ }^{\circ} \mathrm{C}\right)$ & 9 \\
\hline Mean annual rainfall $(\mathrm{mm})$ & 430 \\
\hline
\end{tabular}

$\mathrm{mg}^{-1}$ ) is the reciprocal of LMA (SLA=1/LMA) and expresses the leaf surface development per mass unit. SLA is positively correlated with moisture and nutrient availability and is mainly determined by leaf density and thickness (Ackerly et al. 2002). DMC ( $\mathrm{mg} \mathrm{cm}^{-3}$ ) is the dry mass per volume of plant organ.

\section{Data analysis}

We employed two-way ANOVA and independent-sample $t$-test for all variables to investigate the effects of altitude (low, high), the position of trees (forest edge, forest understory, and isolated trees), and the orientation in the crown ( N, S, E, and $\mathrm{W}$ ) on leaf morphology. Differences were considered significant at $p<0.05$ level. It is worth to stress that all the results have been analyzed at the community level over the study area by pooling the different species. A boxplot was also used to compare morphological traits of leaves among sites. XLSTAT ${ }^{\oplus}$ ver. 2019.1 (Addinsoft, Paris, France) was used for all analyses. All values presented are means \pm standard error.

\section{Results}

\section{Variations of leaf traits at different \\ altitudes}

Foliar morphological traits of woody species in the study area at two different altitudes (1300-1500 m and 1500-1700 m a.s.l.) were investigated to establish their response to varying altitudes. Except for LW, $L L$, and LA, all measured leaf traits showed a significant difference $(p<0.05)$ between

Tab. 2 - General characteristics of the sampling sites of Fandoghlo region at Namin, Ardabil, Iran.

\begin{tabular}{|c|c|c|c|c|c|}
\hline Sites & $\begin{array}{c}\text { Canopy cover } \\
(\%)\end{array}$ & $\begin{array}{l}\text { Altitude } \\
\text { (m) }\end{array}$ & $\begin{array}{l}\text { No. } \\
\text { Trees }\end{array}$ & $\begin{array}{c}\text { Slope } \\
\left({ }^{\circ}\right)\end{array}$ & Dominant canopy species \\
\hline Forest edge (FE) & $65.45 \pm 5.20$ & \multirow{2}{*}{$\begin{array}{c}1300-1500 \\
\text { (Low) }\end{array}$} & \multirow{2}{*}{45} & \multirow{2}{*}{$0-15$} & \multirow{2}{*}{$\begin{array}{l}\text { Acer campestre, Carpinus betulus, Corylus avellana, } \\
\text { Crataegus meyeri, Crataegus microphylla, Frangula alnus } \\
\text { Mill., Malus orientalis, Populus deltoides Bartr. ex Marsh., } \\
\text { Prunus divaricata, Quercus macranthera, Quercus } \\
\text { castaneaefolia, Salix aegyptiaca L., Viburnum opulus L. }\end{array}$} \\
\hline Isolated trees (IT) & - & & & & \\
\hline Forest edge (FE) & $45.00 \pm 8.50$ & \multirow{3}{*}{$\begin{array}{c}1500-1700 \\
\text { (High) }\end{array}$} & \multirow{3}{*}{45} & \multirow{3}{*}{$0-23$} & \multirow{3}{*}{$\begin{array}{l}\text { Carpinus betulus, Crataegus meyeri, Crataegus microphylla, } \\
\text { Cornus mas, Fraxinus excelsior, Malus orientalis, Mespilus } \\
\text { germanica, Punica granatum, Prunus divaricata, Quercus } \\
\text { castaneaefolia, Quercus macranthera, Rosa canina L. }\end{array}$} \\
\hline Forest understory (FU) & $55.52 \pm 10.15$ & & & & \\
\hline Isolated trees (IT) & - & & & & \\
\hline
\end{tabular}


Tab. 3 - List of the 18 tree species sampled in the study area.

\begin{tabular}{lllc}
\hline $\begin{array}{l}\text { Species } \\
\text { Code }\end{array}$ & Family & Scientific Name & $\begin{array}{c}\text { No. } \\
\text { Trees }\end{array}$ \\
\hline $\mathrm{Ac}$ & Sapindaceae & Acer campestre & 4 \\
\hline $\mathrm{Vi}$ & Adoxaceae & Viburnum opulus & 4 \\
$\mathrm{Co} 1$ & Betulaceae & Corylus avellana & 4 \\
\hline $\mathrm{Ca}$ & Carpinus betulus & 4 \\
\hline $\mathrm{Co} 2$ & Cornaceae & Cornus mas & 4 \\
\hline Qu1 & Fagaceae & Quercus castaneaefolia & 6 \\
\hline Qu2 & & Quercus macranthera & 4 \\
\hline Pu & Lythraceae & Punica granatum & 4 \\
\hline Fr1 & Oleaceae & Fraxinus excelsior & 4 \\
\hline Fr2 & Rhamnaceae & Frangula alnus & 4 \\
\hline Cr1 & & Crataegus meyeri & 8 \\
\hline Cr2 & & Crataegus microphylla & 10 \\
\hline Ma & \multirow{2}{*}{ Rosaceae } & Malus orientalis & 6 \\
\hline Me & & Mespilus germanica & 6 \\
\hline Pr & & Prunus divaricata & 6 \\
\hline Ro & & Rosa canina & 4 \\
\hline Po & \multirow{2}{*}{ Salicaceae } & Populus deltoides & 4 \\
\hline Sa & & Salix aegyptiaca & 4 \\
\hline
\end{tabular}

the two altitudinal zones considered (Tab. 4). LW ranged from 0.85 to $13.2 \mathrm{~cm}$ with an average of $4.7 \mathrm{~cm}$ at low altitude, while at high altitude it ranged from 0.93 to 10.81 $\mathrm{cm}$, with an average of $4.39 \mathrm{~cm}$ (Fig. 2). The mean LL was $7.81 \mathrm{~cm}$ and $7.21 \mathrm{~cm}$ at low and high altitudes, respectively. The average LA at low altitude was $27.95 \mathrm{~cm}^{2}$ ranging from 3.55 to $63.25 \mathrm{~cm}^{2}$; at high altitude, average LA was 24.15 , ranging from 2.52 to $59.32 \mathrm{~cm}^{2}$. The average LT was lower at high altitude $(184.29 \mu \mathrm{m})$ than at low altitude $(231.08 \mu \mathrm{m})$. Regarding water relations, WC was the highest at high altitudes; the average WC was $34.63 \%$ and $43.75 \%$ at low and high altitudes, respectively. SLA in trees from low altitudes ranged from 0.52 to $13.27 \mathrm{~cm}^{2} \mathrm{mg}^{-1}$, with an average of 3.31 $\mathrm{cm}^{2} \mathrm{mg}^{-1}$, which by far exceeded that of trees from high altitude (average of 5.37 $\mathrm{cm}^{2} \mathrm{mg}^{-1}$ ). The opposite pattern was found regarding LMA, irrespective of the position of the trees along the gradient of canopy cover (Fig. 2). The average LMA was 6.01 and $4.39 \mathrm{mg} \mathrm{cm}^{-2}$ at low and high altitudes, respectively. DMC at low altitude was ranging from 0.08 to $2.46 \mathrm{mg} \mathrm{cm}^{-3}$, with an aver- age of $0.6 \mathrm{mg} \mathrm{cm}^{-3}$, and was significantly higher than that at high altitude, ranging from 0.06 to $1.82 \mathrm{mg} \mathrm{cm}^{-3}$, with an average of $0.5 \mathrm{mg} \mathrm{cm}^{-3}$.

Almost all the traits tended to be lower at high altitude than at low altitude, except WC and SLA, regardless of the position of the sampled tree (FU, FE, IT - Fig. 2). Also, the results showed that $L T$ reduced significantly with increasing altitude (from 234.34 \pm 13.17 to $186.39 \pm 13.03 \mu \mathrm{m}, \mathrm{p}<0.001)$. In contrast, LMA increased significantly ( $p<0.001$ ) from $6.01 \pm 0.72 \mathrm{mg} \mathrm{cm}^{-2}$ at low altitude to $4.39 \pm 0.48 \mathrm{mg} \mathrm{cm}^{-2}$ at high altitude. Both WC and SLA increased significantly $(p<0.001)$ from low to high altitudes.

\section{Variations of leaf traits along the} gradient of canopy cover

The position of sampled trees along the gradient of canopy cover (FU, FE, IT) had a significant effect on all morphological traits $(p<0.05)$. Average LW was $5.19 \mathrm{~cm}$ at forest edges (FE), $4.92 \mathrm{~cm}$ at forest understory (FU), and $4.03 \mathrm{~cm}$ for isolated trees (IT). Additionally, the mean LL was 9.21, 7.97, and $6.46 \mathrm{~cm}$ for the leaves collected at for- est edge, forest understory, and from isolated trees, respectively. LA differed significantly from FE and FU (about $32 \mathrm{~cm}^{2}$ ) to IT (about $20 \mathrm{~cm}^{2}$ ). We found that leaves of trees from the forest edge were ticker (mean LT $=256.08 \mu \mathrm{m}$, range $=109-445$ $\mu \mathrm{m})$ as compared with leaves from forest understory and isolated trees (mean LT of 220.29 and $177.16 \mu \mathrm{m}$, respectively). WC was slightly different among the three positions. LMA and SLA differed significantly between FE and FU ( $p<0.05)$, but these traits in the IT were close to those of FE. Mean LMA ranged from $3.64 \mathrm{mg} \mathrm{cm}^{-2}$ at the forest understory to $6.10 \mathrm{mg} \mathrm{cm}^{-2}$ in isolated trees, and $5.19 \mathrm{mg} \mathrm{cm}^{-2}$ at the forest edge. On average, the values of SLA in FE, FU, and IT were $4.15,5.72$, and $3.65 \mathrm{~cm}^{2}$ $\mathrm{mg}^{-1}$, respectively. Moreover, the mean values of DMC were 0.39 and $0.43 \mathrm{mg} \mathrm{cm}^{-3}$ at the forest edge and forest understory, respectively, while in the isolated trees the mean DMC was $0.74 \mathrm{mg} \mathrm{cm}^{-3}$ (Fig. 3). Furthermore, species with different positions had different responses in the different altitudinal zones. Leaf size parameters (LW, $\mathrm{LL}, \mathrm{LA}$, and $\mathrm{LT}$ ) tended to be lower at high altitude than at low altitude for FE and FU, but this trend was the opposite for IT. However, these differences were not significant among the three different positions, except for LL and LT in isolated trees and forest edge, respectively (Tab. 5). SLA was significantly higher in forest understory than at forest edge only at low altitude. At the same time, all other traits were significantly higher $(p<0.05)$ at the forest edge than in forest understory, regardless of low or high altitude (Tab. 5, Fig. 2).

Interaction of the position of trees along the gradient of canopy cover and altitude had a significant effect on LL, LT, and SLA $(p<0.001)$. It should be noted that for isolated trees, the level of LL at high altitude was considerably higher than low altitude $(p<0.05)$. However, this parameter showed no significant differences between FE and FU to their altitude. LT at high altitude was significantly lower $(p<0.001)$ than at low altitude in $\mathrm{FE}$, though no significant differences for this parameter were found between the two altitudinal ranges in FU and IT (Tab. 5, Fig. 2). WC showed an overall trend of increase with increasing altitude,

Tab. 4 - ANOVA summary of the effect of altitude, position of the trees, crown orientation, and their interactions on leaf morpholog ical traits of woody species in the study area. F-values and significance levels are displayed. (df): degrees of freedom; ( $* * *): p<0.001$; $(* *)$ : $p<0.01 ;(*): p<0.05$ (ns): not significant.

\begin{tabular}{|c|c|c|c|c|c|c|c|c|c|}
\hline Effect & df & $\begin{array}{l}\mathrm{LW} \\
(\mathrm{cm})\end{array}$ & $\begin{array}{l}\mathrm{LL} \\
(\mathrm{cm})\end{array}$ & $\begin{array}{c}\mathrm{LA} \\
\left(\mathrm{cm}^{2}\right)\end{array}$ & $\begin{array}{c}\mathrm{LT} \\
(\mu \mathrm{m})\end{array}$ & $\begin{array}{l}\text { WC } \\
\text { (\%) }\end{array}$ & $\begin{array}{c}\text { LMA } \\
\left(\mathrm{mg} \mathrm{cm}^{-2}\right)\end{array}$ & $\begin{array}{c}\text { SLA } \\
\left(\mathrm{cm}^{2} \mathrm{mg}^{-1}\right)\end{array}$ & $\begin{array}{c}\text { DMC } \\
\left(\mathrm{mg} \mathrm{cm}^{-3}\right)\end{array}$ \\
\hline Altitude (low, high) & 1 & $0.01^{\text {ns }}$ & $0.01^{\text {ns }}$ & $0.03^{\text {ns }}$ & $8.46^{* *}$ & $40.45^{* * *}$ & $18.48^{* * *}$ & $33.72^{* * *}$ & $5.52^{*}$ \\
\hline Position of the trees (FE, FU, IT) & 2 & $3.59^{*}$ & $17.44^{* * *}$ & $16.57^{* * *}$ & $18.16^{* * *}$ & $4.31^{*}$ & $6.79^{* *}$ & $13.3^{* * *}$ & $8.61^{* * *}$ \\
\hline Orientation of the crown $(\mathrm{N}, \mathrm{S}, \mathrm{W}, \mathrm{E})$ & 3 & $0.11^{\mathrm{ns}}$ & $0.24^{\mathrm{ns}}$ & $0.08^{\text {ns }}$ & $0.23^{\text {ns }}$ & $1.02^{\text {ns }}$ & $0.31^{\mathrm{ns}}$ & $0.29^{\text {ns }}$ & $0.15^{\mathrm{ns}}$ \\
\hline Altitude $\times$ Position of the trees & 2 & $1.86^{\mathrm{ns}}$ & $4.36^{*}$ & $2.15^{\text {ns }}$ & $10.79^{* * *}$ & $0.83^{\text {ns }}$ & $2.83^{\text {ns }}$ & $4.09^{*}$ & $2.12^{\mathrm{ns}}$ \\
\hline Altitude $\times$ Orientation of the crown & 3 & $0.25^{\mathrm{ns}}$ & $0.66^{\mathrm{ns}}$ & $0.19^{\text {ns }}$ & $0.03^{\text {ns }}$ & $0.26^{\mathrm{ns}}$ & $0.55^{\mathrm{ns}}$ & $0.22^{\text {ns }}$ & $0.54^{\mathrm{ns}}$ \\
\hline Position of the tree $\times$ Orientation of the crown & 6 & $0.01^{\text {ns }}$ & $0.01^{\text {ns }}$ & $0.02^{\text {ns }}$ & $0.10^{\text {ns }}$ & $0.17^{\mathrm{ns}}$ & $0.06^{\text {ns }}$ & $0.11^{\mathrm{ns}}$ & $0.09^{\text {ns }}$ \\
\hline
\end{tabular}



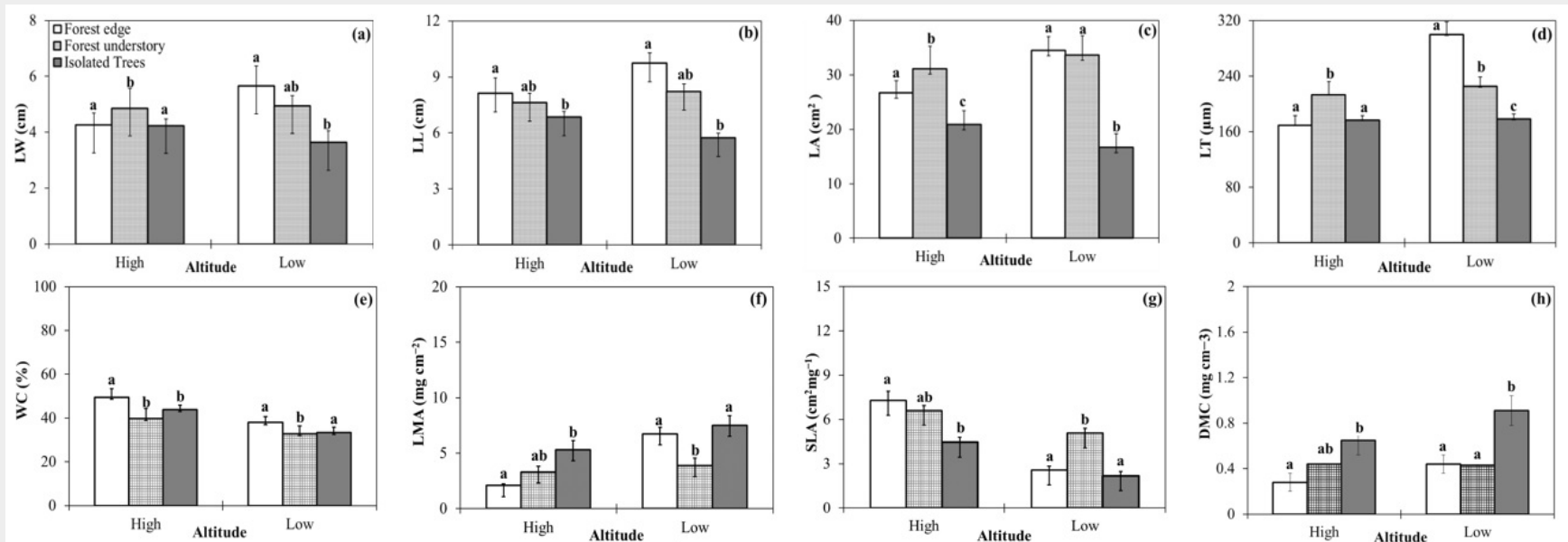

Fig. 2 - Differences in leaf morphological traits between two altitudes (low, high) in forest edge, forest understory, and isolated trees. (LW): leaf width; (LL): leaf length; (LA): leaf area; (LT): leaf thickness; (WC): water content; (LMA): leaf mass per area; (SLA): specific leaf area; (DMC): dry matter concentration. Data are shown as average \pm SE. The same letters indicate no significant differ ence $(p<0.05)$ between means.
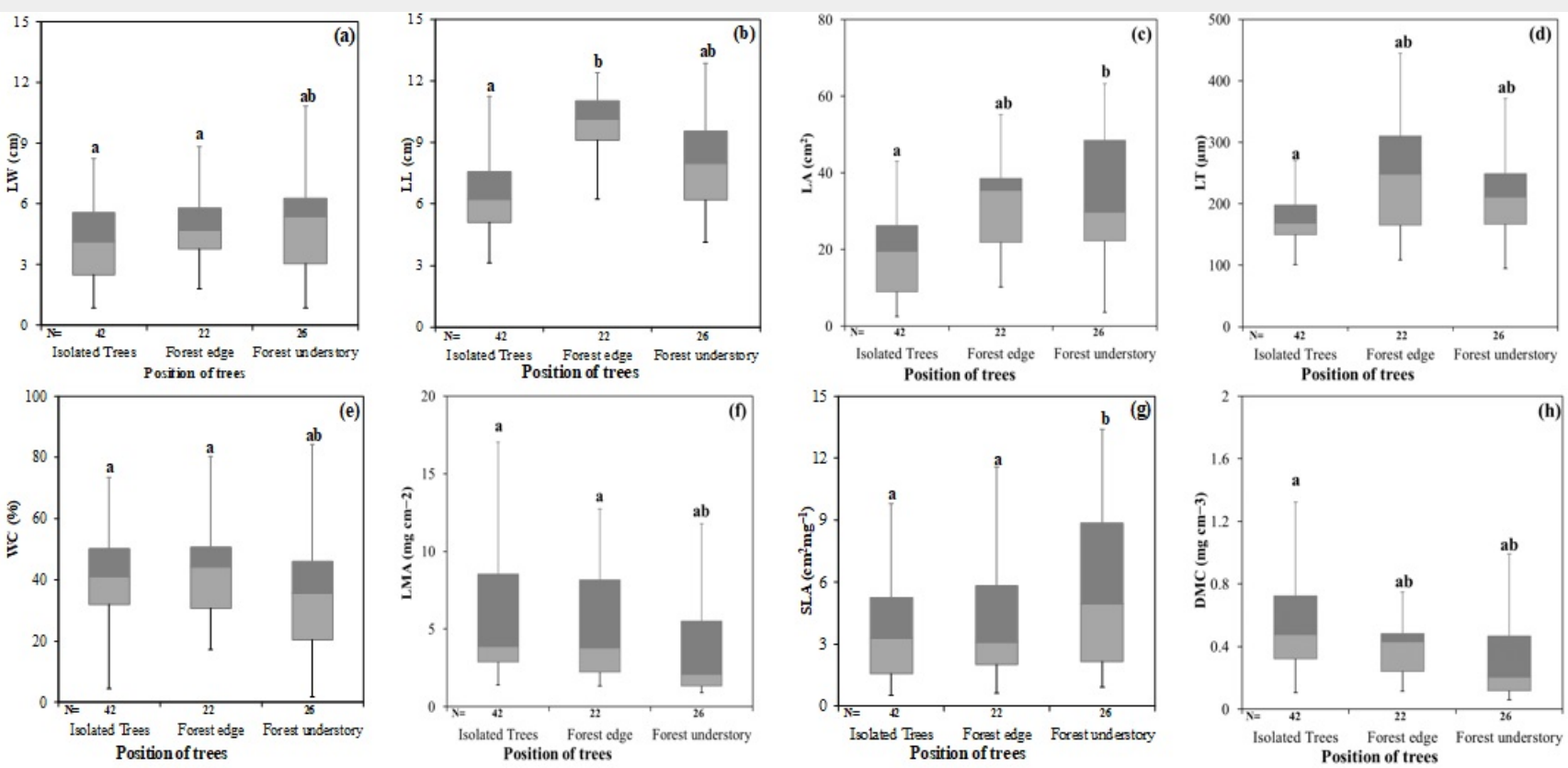

Fig. 3 - Paired boxplots of leaf morphological traits by the position of trees along a gradient of canopy cover (forest edge, forest understory, and isolate trees). Boxes with the same letter indicate means that were not significantly different $(p<0.05)$.

Tab. 5 - Mean values ( \pm SE) of leaf morphological traits for different positions of trees along a gradient of canopy cover (FE, FU, IT) at low (1300-1500 $\mathrm{m}$ a.s.I.) or high (1500-1700 $\mathrm{m}$ a.s.I.) elevation. $t$-values and significance of differences after $t$-test are given. $(* * *)$ : $\mathrm{p}<0.001 ;(* *): p<0.01 ;(*): p<0.05 ;(n s):$ not significant.

\begin{tabular}{|c|c|c|c|c|c|c|c|c|c|}
\hline \multirow{2}{*}{ Leaf traits } & \multicolumn{2}{|c|}{ Forest edge (FE) } & \multirow{2}{*}{$t$} & \multicolumn{2}{|c|}{ Forest understory (FU) } & \multirow{2}{*}{$t$} & \multicolumn{2}{|c|}{ Isolated trees (IT) } & \multirow{2}{*}{$t$} \\
\hline & Low & High & & Low & High & & Low & High & \\
\hline LW (cm) & $5.66 \pm 0.71$ & $4.26 \pm 0.42$ & $-1.31^{\text {ns }}$ & $4.95 \pm 0.36$ & $4.86 \pm 0.70$ & $-0.13^{\text {ns }}$ & $3.64 \pm 0.42$ & $4.24 \pm 0.23$ & $1.36^{\mathrm{ns}}$ \\
\hline LL (cm) & $9.75 \pm 0.53$ & $8.14 \pm 0.82$ & $-1.64^{\text {ns }}$ & $8.23 \pm 0.41$ & $7.62 \pm 0.50$ & $-0.91^{\text {ns }}$ & $5.75 \pm 0.25$ & $6.84 \pm 0.31$ & $2.36^{*}$ \\
\hline $\mathrm{LA}(\mathrm{cm} 2)$ & $34.47 \pm 2.51$ & $26.67 \pm 2.22$ & $-1.95^{\mathrm{ns}}$ & $33.63 \pm 3.51$ & $31.11 \pm 4.17$ & $-0.45^{\mathrm{ns}}$ & $16.67 \pm 2.53$ & $20.89 \pm 1.24$ & $1.66^{\mathrm{ns}}$ \\
\hline $\mathrm{LT}(\mu \mathrm{m})$ & $299.54 \pm 18.41$ & $169.17 \pm 13.71$ & $-4.56^{4+*}$ & $225.18 \pm 13.66$ & $213.45 \pm 18.58$ & $-0.51^{\text {ns }}$ & $178.29 \pm 7.45$ & $176.56 \pm 6.80$ & $-0.16^{\mathrm{ns}}$ \\
\hline WC (\%) & $38.04 \pm 7.58$ & $49.52 \pm 28.25$ & $3.33^{*+* *+}$ & $32.87 \pm 5.62$ & $39.82 \pm 3.47$ & $3.51^{* * * *}$ & $42.72 \pm 7.27$ & $38.76 \pm 8.10$ & $4.54^{+*+1}$ \\
\hline LMA $\left(\mathrm{mg} \mathrm{cm}^{-2}\right)$ & $5.77 \pm 6.65$ & $3.64 \pm 0.22$ & $-4.33^{+*+*}$ & $4.71 \pm 4.23$ & $3.41 \pm 3.53$ & $-1.03^{\text {ns }}$ & $6.70 \pm 6.95$ & $5.21 \pm 5.01$ & $-2.80^{*+*+}$ \\
\hline $\operatorname{SLA}\left(\mathrm{cm}^{2} \mathrm{mg}^{-1}\right)$ & $3.89 \pm 0.26$ & $3.70 \pm 0.64$ & $8.45^{* * * *}$ & $3.32 \pm 0.64$ & $6.82 \pm 0.92$ & $1.37^{\mathrm{ns}}$ & $3.08 \pm 0.32$ & $5.26 \pm 0.34$ & $4.32^{+*+*}$ \\
\hline DMC $\left(\mathrm{mg} \mathrm{cm}^{-3}\right)$ & $0.42 \pm 0.02$ & $0.87 \pm 0.01$ & $-4.21^{* * *+*}$ & $0.61 \pm 0.04$ & $0.39 \pm 0.04$ & $-0.001^{\text {ns }}$ & $0.74 \pm 0.05$ & $0.53 \pm 0.04$ & $-2.76^{* *}$ \\
\hline
\end{tabular}


Tab. 6 - The main effects of the different orientation of tree crown $( \pm$ SE) on leaf traits.

\begin{tabular}{lcccc}
\hline \multirow{2}{*}{ Leaf traits } & \multicolumn{4}{c}{ Orientation of the crown } \\
\cline { 2 - 5 } & North & South & East & West \\
\hline LW $(\mathrm{cm})$ & $4.39 \pm 0.37$ & $4.68 \pm 0.38$ & $4.61 \pm 0.38$ & $4.48 \pm 0.37$ \\
\hline LL $(\mathrm{cm})$ & $7.35 \pm 0.39$ & $7.69 \pm 0.40$ & $7.63 \pm 0.39$ & $7.36 \pm 0.40$ \\
\hline LA $\left(\mathrm{cm}^{2}\right)$ & $25.80 \pm 2.33$ & $26.58 \pm 2.46$ & $26.45 \pm 2.40$ & $25.18 \pm 2.28$ \\
\hline LT $(\mu \mathrm{m})$ & $211.00 \pm 11.93$ & $200.56 \pm 10.95$ & $211.10 \pm 13.38$ & $205.78 \pm 11.81$ \\
\hline WC $(\%)$ & $36.51 \pm 8.36$ & $38.69 \pm 7.45$ & $40.81 \pm 8.35$ & $41.22 \pm 10.23$ \\
\hline LMA $\left(\mathrm{mg} \mathrm{cm}^{-2}\right)$ & $5.24 \pm 0.44$ & $4.91 \pm 0.65$ & $5.46 \pm 0.80$ & $5.18 \pm 0.69$ \\
\hline SLA $\left(\mathrm{cm}^{2} \mathrm{mg}^{-1}\right)$ & $4.48 \pm 0.49$ & $4.49 \pm 0.50$ & $3.99 \pm 0.44$ & $4.47 \pm 0.52$ \\
\hline DMC $\left(\mathrm{mg} \mathrm{cm}^{-3}\right)$ & $0.56 \pm 0.04$ & $0.57 \pm 0.04$ & $0.60 \pm 0.04$ & $0.56 \pm 0.03$ \\
\hline
\end{tabular}

especially at the forest edge and in forest understory (Tab. 5, Fig. 2). LMA of all species decreased with increasing altitudes. SLA of all species showed an overall trend of increase with increasing altitudes. Furthermore, the DMC of species in FE and IT showed a decrease along the altitude gradient. There was no noticeable effect of elevation on DMC in the forest understory. The effect of the different positions of the sampled trees on leaf traits is also shown in Fig. 3 .

\section{Variations of leaf traits in different} orientation of the crown

The main effects of altitude and crown orientation on leaf trait variation are presented in Tab. 4 and Tab. 6. We found no significant difference ( $p>0.05)$ in the mean values of leaf morphological traits among different orientations of the crown (Tab. 4). Furthermore, there were no significant differences $(p>0.05)$ in the interactions of the orientation of the crown with altitude, as well as the position of the trees (Tab. 4).

\section{Discussion}

\section{Variations of leaf traits at different altitudes}

Our results confirmed that altitude had remarkable effects on almost all leaf morphological traits of the woody plant community. Leaf water content (WC) and specific leaf area (SLA) at high altitude (1500$1700 \mathrm{~m}$ a.s.l.) had values higher than those at low altitude (1300-1500 m a.s.l.), while all other parameters investigated, such as leaf area (LA), were significantly higher at lower altitudes. Higher values of leaf size parameters at low altitude might result from lower light due to understory competition, suggesting a higher environmental stress at low altitude (Li et al. 2014).

This result can also provide some indications on the physiological drought conditions at high altitudes due to low air temperature, soil depth, high wind speed, and the short vegetative periods (Kao \& Chang 2001, Li et al. 2014). According to Paridari et al. (2013), trees at the higher altitude have smaller leaf lamina than those at lower altitudes. Moreover, it has been reported that tree populations from higher altitudes generally exhibit reduced growth, as well as smaller and thicker leaves (Petit et al. 2011). In this study, the effect of the shortened growing season with increasing altitude is evident in the decreased leaf thickness (LT). However, such effect is controversial in the literature, as in some cases an increased altitude has been claimed to result in thicker leaves (mainly due to intense irradiance - Bussotti et al. 1998), while in other cases in thinner leaves (Suzuki 1998), reflecting the drought conditions at high altitudes which hamper leaf growth. We found that leaf mass per area (LMA) decreased $(p<0.001)$ with increasing altitude. High LMA under low-light conditions does not enhance light capture (Evans \& Poorter 2001). This result is consistent with the findings of Paridari et al. (2013) in the Hyrcanian forest, where LMA was higher at low altitudes. In contrast, the results of some studies confirmed that leaves at high altitudes had higher LMA than at lower altitudes (Rajsnerová et al. 2015), suggesting that different leaf properties may be fostered under different environmental conditions. Among leaf traits, LMA, or its inverse value SLA, has been frequently used as an indicator of differential functional strategies in plant species (Wright et al. 2004, Domínguez et al. 2012). The low LMA/high SLA leaves of trees could also respond to low photosynthate concentrations (Pierce et al. 2012). In contrast, high values of LMA can be the consequence of a high density of mesophyll tissues, or leaf thickness. This could lead to misinterpretations of the ecological significance of LMA, since DMC and LT have different ecological interpretations (Lamont et al. 2002). Both WC and SLA increased $(p<0.001)$ with increasing altitude. Higher SLA at high altitude reflects a high capacity to absorb active photosynthetic radiation (Poorter et al. 2009, Li et al. 2014). This result is in contrast with previous studies reporting that SLA decreases with increasing altitude as a likely response to decreasing temperature rather than increasing radiation (Körner 2003) or changes in water availability (Poorter et al. 2009). Our findings suggest that leaves generally respond to changes in altitude with a reduction of several morphological traits such as LW, LL, LA, and LT. At the same time, a general increase in water relations in terms of WC and SLA was observed. These results highlight the influence of altitude on plant physiological parameters and consequently on the autoecology of the species.

\section{Variations of leaf traits under different canopy cover}

In this study, the variation of leaf morphological traits of species reflected the heterogeneous light environment (in terms of sunlight radiation) which occurs in different locations of the forest environment, such as in the understory, at the forest edge, and in open spaces. Indeed, we observed that the position of the sampled trees along the gradient of canopy cover had a substantial effect on leaf morphological traits of the tree species considered. All morphological traits except SLA were higher at the forest edge than in the forest understory. At higher light environments, SLA tended to decrease ( $\mathrm{Li}$ et al. 2014, Larcher et al. 2015), as observed in the present study. LMA increases with decreasing forest cover, likely due to the increased light availability and water stress (Neyret et al. 2016). The results of this study also showed a significant increase in LMA with increasing light at the isolated trees, similar to the findings of previous studies (Sprugel et al. 1996, Wang et al. 2006). LMA and DMC were significantly higher in isolated trees than at the forest edge and in the understory, regardless of low or high altitude $(p<0.001)$. The low LMA and DMC observed in this study in forest edge and forest understory is consistent with the findings of Liu et al. (2019), as higher moisture and lower evaporation under low light favor a high leaf water content, thus leading to a lower leaf dry mass to fresh mass ratio. Results for the effect of canopy cover and altitude on morphology showed that in forest edge and forest understory, leaf size parameters (LW, LL, LA, and LT) decreased at higher altitude due to the change of moisture and temperature conditions. In contrast, the parameters increased in the case of isolated trees under full light. The high WC might be due to the reduction of LA with increasing altitude (Wang et al. 2018). LMA decreased with increasing altitude for all trees in three different sites. LMA at high altitude was significantly lower than at low altitude at forest edge and in isolated trees $(p<0.001)$; however, this decrease is not significant in the forest understory. DMC decreased in forest edge and isolated trees with increasing altitude, and such effect was not significant in the forest understory. Generally, a high DMC indicates few intercellular spaces and a high mesophyll resistance to the diffusion of gases. These features are detrimental to photosynthetic function due to the low availability of $\mathrm{CO}_{2}$ within the mesophyll. Also, the DMC increases following many 
environmental stresses, such as oxidative planning further research projects. stress (Bussotti 2008).

\section{Variations of leaf traits at different} orientation of the crown

The differences between the data measured were not significant for any crown orientation. This result could not have been explained in this study, and further studies should focus on this topic. However, this finding confirms previous studies showing no significant differences in the main leaf features among different geographical sides of the crown (Yousefzadeh et al. 2010). Nonetheless, some previous studies have reported that various orientations of the crown differ significantly in respect of some leaf morphological characteristics, due to differences in light environment (lio et al. 2005, Kitajima et al. 2005, Kok \& Bahar 2015).

\section{Conclusions}

We carried out in situ observations of leaf morphological traits by sampling 18 different deciduous woody species at their full leaf expansion. Due to differences in light and water conditions, the growth rate of singular leaves may be influenced by their position within the canopy and across the stand. We also considered isolated trees in the open field with a few other trees nearby. Leaf morphological traits varied considerably between the two altitudinal ranges and at different positions of the sampled trees along the light gradient. Overall, most leaf traits, including leaf width, length, area, and thickness, decreased significantly with increasing altitude. Furthermore, water relations, such as water content and specific leaf area ratios markedly increased. There were significant positive relationships between both altitude and position of the trees on the one hand and leaf morphological traits on the other. In contrast, both were negatively related to the orientation of the crown. Altitude and position of the trees were significant for all morphological traits of the species (except for the effect of altitude on leaf width, length, and area).

The results confirmed that, in terms of leaf morphology, all the species analyzed had similar responses to the heterogeneous light environment occurring at different locations characterized by different canopy cover. All leaf morphological traits except SLA tended to be higher at the forest edge and at lower altitudes than in forest understory and at higher altitudes. These results indicate that species shift their morphological characters to adapt to a specific environment and confirm earlier reports on the response of plants to changes in environmental parameters. Information about variability in both leaf morphological and ecophysiological traits, and its roles in growth, development, and productivity of trees and shrubs in a forest ecosystem, is needed for foresters and forest scientists for forest management and

\section{References}

Ackerly DD, Knight CA, Weiss SB, Barton K, Starmer KP (2002). Leaf size, specific leaf area and microhabitat distribution of chaparral woody plants: contrasting patterns in species level and community level analyses. Oecologia 130: 449-457. - doi: 10.1007/s004420100805

Akbarian MR, Tabari M, Akbarinia M, Zarafshar M, Meave Del Castillo JA, Yousefzadeh H, Sattarian A (2011). Effects of elevational gradient on leaf and stomatal morphology of Caucasian alder (Alnus subcordata) in the Hyrcanian forest, Iran. Folia Oecologica 38: 203-224. [online] URL: http://www.researchgate.net/publication/ 281347968

Akinlabi AA, Jimoh MA, Saheed SA (2014). Effects of altitudinal gradients on morphoanatomical characters of Chromolaena odorata (L.) King \& Robinson. FUTA Journal of Research in Sciences 2: 150-156.

Begon M, Fitter A, Macfadyen A (1990). Advances in ecological research ( $1^{\text {st }}$ edn). Academic Press, London, UK, vol. 20, pp. 1-281. [online] URL: http://books.google.com/books?id=I u Ilwnogvic

Bo-dor P, Baranyai L, Parrag V, Bisztray GYD (2014). Effect of row orientation and elevation on leaf morphology of Grapevine (Vitis vinifera L.) cv. Furmint. Progress in Agricultural Engineering Sciences 10: 53-69. - doi: 10.1556/Prog ress.10.2014.4

Bussotti F, Gravano E, Grossoni P, Tani C (1998). Occurrence of tannins in leaves of beech trees (Fagus sylvatica) along an ecological gradient, detected by histochemical and ultrastructural analyses. New Phytologist 138 (3): 469-479. doi: 10.1046/j.1469-8137.1998.00121.x

Bussotti $F$ (2008). Functional leaf traits, plant communities and acclimation processes in relation to oxidative stress in trees: a critical overview. Global Change Biology 14: 2727-2739. doi: 10.1111/j.1365-2486.2008.01677.x

Bussotti F, Pollastrini M (2015). Evaluation of leaf features in forest trees: methods, techniques, obtainable information and limits. Ecological Indicators 52: 219-230. - doi: 10.1016/j.ecolind.201 4.12.010

De la Riva EG, Olmo M, Poorter H, Ubera JL, Villar R (2016). Leaf mass per area (LMA) and its relationship with leaf structure and anatomy in 34 Mediterranean woody species along a water availability gradient. PLoS One 11 (2): e0148788. - doi: 10.1371/journal.pone.0148788

Domínguez MT, Aponte C, Pérez-Ramos IM, García LV, Villar R, Marañón T (2012). Relationships between leaf morphological traits, nutrient concentrations and isotopic signatures for $\mathrm{Me}$ diterranean woody plant species and communities. Plant Soil 357: 407-424. - doi: 10.1007/s111 04-012-1214-7

England JR, Attiwill PM (2006). Changes in leaf morphology and anatomy with tree age and height in the broadleaved evergreen species, Eucalyptus regnans F. Muell. Trees 20: 79-90. doi: 10.1007/s00468-005-0015-5

Evans JR, Poorter H (2001). Photosynthetic acclimation of plants to growth irradiance: the relative importance of specific leaf area and nitrogen partitioning in maximizing carbon gain.
Plant, Cell and Environment 24: 755-767. - doi: 10.1046/j.1365-3040.2001.00724.x

Guerin GR, Wen H, Lowe AJ (2012). Leaf morphology shift linked to climate change. Biology Letters 8: 882-886. - doi: 10.1098/rsbl.2012.0458 Hamzehee B, Nobakht M, Asri Y, Bakhshi Khaniki $G$ (2018). Evaluation of morphological changes of Crataegus meyeri Pojark in relation to some climatic parameters in Iran. Nova Biologica Reperta 4 (4): 320-328. - doi: 10.29252/nbr.4.4.320 Hansen G, Malmkjr K, Gile D (2004). Claims, changes and challenges in translation studies: selected contributions from the EST Congress, Copenhagen 2001. John Benjamins Publishing Company, Benjamins Translation Library no. 50, Amsterdam, Netherlands, pp. 320. [online] URL: http://books.google.com/books?id=1bY9A AAAQBAJ

Holland N, Richardson AD (2009). Stomatal length correlates with elevation of growth in four temperate species. Journal of Sustainable Forestry 28: 63-73. - doi: 10.1080/10549810802 626142

Hovenden MJ, Vander Schoor JK (2006). The response of leaf morphology to irradiance depends on altitude of origin in Nothofagus cunninghamii. New Phytologist 169: 291-297. - doi: 10.1111/j.1469-8137.2005.01585.x

lio A, Fukasawa $\mathrm{H}$, Nose $\mathrm{Y}$, Kato S, Kakubari $\mathrm{Y}$ (2005). Vertical, horizontal and azimuthal variations in leaf photosynthetic characteristics within a Fagus crenata crown in relation to light acclimation. Tree Physiology 25 (5): 533-44. doi: 10.1093/treephys/25.5.533

Kao WY, Chang KW (2001). Altitudinal trends in photosynthetic rate and leaf characteristics of Miscanthus populations from central Taiwan. Australian Journal of Botany 49: 509-514. - doi: 10.1071/BTooo28

Kitajima K, Mulkey SS, Wright SJ (2005). Variation in crown light utilization characteristics among tropical canopy trees. Annual Botany 95 (3): 535-47. - doi: 10.1093/aob/mcio51

Kok D, Bahar E (2015). Effects of different vineyard altitudes and grapevine directions on some leaf characteristics of cv. Gamay Vitis vinifera L. Bulgarian Journal of Agricultural Science 21 (2): 320-324. [online] URL: http://www. researchgate.net/publication/283736507

Kolodziejek J, Michlewska S (2015). Effect of soil moisture on morpho-anatomical leaf traits of Ranunculus acris (Ranunculaceae). Polish Journal of Ecology 63 (3): 400-413. - doi: 10.3161/150 52249PJE2015.63.3.010

Körner C (2003). Alpine plant life: functional plant ecology of high mountain ecosystems. Springer-Verlag, Berlin, Heidelberg, Germany, pp. 344. [online] URL: http://books.google. com/books?id=uFE2_-Hr6loC

Lamont BB, Groom PK, Cowling RM (2002). High leaf mass per area of related species assemblages may reflect low rainfall and carbon isotope discrimination rather than low phosphorus and nitrogen concentrations. Functional Ecology 16: 403-412. - doi: 10.1046/j.1365-2435. 2002.00631.x

Larcher L, Nogueira G, Boeger MR (2015). Morphological plasticity and gas exchange of Ligustrum lucidum W.T. Aiton in distinct light conditions. Brazilian Archives of Biology and Technology 58 (6): 877-885. - doi: 10.1590/S1516-8913201 
5060439

Li QY, Zhang ZW, Tao JP, Liu JH, Yong XH, Meng XF, Li Z, Wang YJ (2014). Effect of elevation and canopy condition on morphological traits and leaf fluctuating asymmetry of a bamboo, Chimonobambusa utilis in Jinfo Mountain Nature Reserve, Southwest China. Sains Malaysiana 43 (8): 1119-1125.

Li MH, Jiang $Y$, Wang A, Li X, Zhu W, Yan CF, Du $Z$, Shi Z, Lei J, Schönbeck L, He P, Yu FH, Wang $X$ (2018). Active summer carbon storage for winter persistence in trees at the cold alpine treeline. Tree Physiology 38 (9): 1345-1355. - doi: 10.1093/treephys/tpy020

Liu C, Li Y, Xu L, Chen Z, He N (2019). Variation in leaf morphological, stomatal, and anatomical traits and their relationships in temperate and subtropical forests. Scientific Reports 9 (1): 20684. - doi: 10.1038/s41598-019-42335-2

Milla R, Giménez-Benavides L, Escudero A, Reich $P B$ (2009). Intra and interspecific performance in growth and reproduction increase with altitude: a case study with two Saxifraga species from northern Spain. Functional Ecology 23: 111118. - doi: 10.1111/j.1365-2435.2008.01484.x

Mohebbi Bijarpas M, Rostami Shahraji T, Samizadeh H (2019a). Changes in leaf morphological characteristics of Fagus orientalis Lipesky along altitudinal gradients (Case study: Gilan forests, Masal). Journal of Forest Research and Development 5 (1): 27-40. [In Persian]

Mohebbi Bijarpas M, Rostami Shahraji T, Samizadeh H (2019b). Effect of elevation gradient on morphological and physiological responses of Fagus orientalis Lipsky leaves in Guilan forests. Iranian Journal of Forest and Poplar Research 26 (4): 577-590. [In Persian]

Neyret M, Bentley LP, Oliveras I, Marimon BS, Marimon-Junior BH, Almeida De Oliveira E, Barbosa Passos F, Castro Ccoscco R, Dos Santos J, Matias Reis S, Morandi PS, Rayme Paucar G, Robles Cáceres A, Valdez Tejeira Y, Yllanes Choque Y, Salinas N, Shenkin A, Asner GP, Díaz S, Enquist BJ, Malhi $Y$ (2016). Examining variation in the leaf mass per area of dominant species across two contrasting tropical gradients in light of community assembly. Ecology Evolution 6 (16): 5674-89. - doi: 10.1002/ece3.2281 Paridari IC, Seyed Gholamali J, Sonboli A, Zarafshar M, Bruschi P (2013). Leaf macro- and micro-morphological altitudinal variability of Carpinus betulus in the Hyrcanian forest (Iran). Journal of Forestry Research 24 (2): 301-307. doi: $10.1007 / \mathrm{s} 11676-013-0353-x$

Petit G, Anfodillo T, Carraro V, Grani F, Carrer M (2011). Hydraulic con-straints limit height growth in trees at high altitude. New Phytologist 189: 241-252. - doi: 10.1111/j.1469-8137.2010. 03455. $x$

Pierce S, Brusa G, Sartori M, Cerabolini BEL (2012). Combined use of leaf size and economics traits allows direct comparison of hydrophyte and terrestrial herbaceous adaptive strategies. Annals of Botany 109: 1047-1053. doi: 10.1093/aob/mcs021

Poorter H, Niinemets U, Poorter L, Wright IJ, Villar R (2009). Causes and consequences of variation in leaf mass per area (LMA): a meta-analysis. New Phytologist 182: 565-588. - doi: 10.1111/j. 1469-8137.2009.02830.x

Pérez-Harguindeguy N, Díaz S, Garnier E, Lavorel S, Poorter H, Jaureguiberry P (2013). New handbook for standardized measurement of plant functional traits worldwide. Australian Journal of Botany 61: 167-234. - doi: 10.1071/BT12225

Rajsnerová P, Klem K, Holub $\mathrm{P}$, Novotná K, Vecerová K, Kozáciková $M$, Rivas-Ubach Jordi Sardans A, Marek MV, Peñuelas J, Urban O (2015). Morphological, biochemical and physiological traits of upper and lower canopy leaves of European beech tend to converge with increasing altitude. Tree Physiology 35: 47-60. - doi: 10.109 3/treephys/tpu104

Soethe N, Lehmann J, Engels C (2008). Nutrient availability at different altitudes in a tropical montane forest in Ecuador. Journal of Tropical Ecology 24: 397-406. - doi: 10.1017/S02664674 $0800504 \mathrm{X}$

Sprugel DG, Brooks JR, Hinckley TM (1996). Effects of light on shoot geometry and needle morphology in Abies amabilis. Tree Physiology 16: 91-98. - doi: 10.1093/treephys/16.1-2.91

Suzuki S (1998). Leaf phenology, seasonal changes in leaf quality and herbivory pattern of Sanguisorba tenuifolia at different altitudes. Oecologia 117: 169-176. - doi: 10.1007/s004420050 645

Teimoorzadeh A, Ghorbani A, Kavianpoor AH (2015). Study on the flora, life forms and chorology of the southeastern of Namin forests (AsiGheran, Fandoghloo, Hasani and Bobini), Ardabil province. Journal of Plant Researches 28 (2): 264-275. [In Persian]

Thinh NC, Kumagai E, Shimono $\mathrm{H}$, Kawasaki $\mathrm{M}$ (2018). Effects of elevated atmospheric $\mathrm{CO}_{2}$ concentration on morphology of leaf blades in Chinese yam. Plant Production Science 21 (4): 311-321. - doi: 10.1080/1343943X.2018.1511377 Wang GG, Bauerle WL, Mudder BT (2006). Effects of light acclimation on the photosynthesis, growth, and biomass allocation in American chestnut. Forest Ecology and Management
226: 173-180. - doi: 10.1016/j.foreco.2005.12.063 Wang YJ, Shi XP, Peng Y, Zhong ZC, Tao JP (2012). Effects of fine-scale pattern of dwarf bamboo on understory species diversity in $\mathrm{Abi}$ es faxoniana forest, southwest China. Sains Malaysiana 41: 649-657. [online] URL: http:// core.ac.uk/download/pdf/11493765.pdf

Wang $A$, Wang $X$, Tognetti R, Lei JP, Pan HL, Liu XL, Jiang $Y$, Wang XY, He P, Yu FH, Li MH (2018). Elevation alters carbon and nutrient concentrations and stoichiometry in Quercus aquifolioides in southwestern China. Science of the Total Environment 622: 1463-1475. - doi: 10.1016/j.scito tenv.2017.12.070

Wright IJ, Reich PB, Westoby M, Ackerly DD, Baruch Z, Bongers F, Cavender-Bares J, Chapin T, Cornelissen JH, Diemer M, Flexas J, Garnier E, Groom PK, Gulias J, Hikosaka K, Lamont BB, Lee T, Lee W, Lusk C, Midgley JJ, Navas ML, Niinemets U, Oleksyn J, Osada N, Poorter H, Poot P, Prior L, Pyankov VI, Roumet C, Thomas SC, Tjoelker MG, Veneklaas EJ, Villar R (2004). The worldwide leaf economics spectrum. Nature 428 (6985): 821-7. - doi: 10.1038/nature02403

Xu M, Ma L, Jia Y, Liu M (2017). Integrating the effects of latitude and altitude on the spatial differentiation of plant community diversity in a mountainous ecosystem in China. PLoS One 12 (3): e0174231. - doi: 10.1371/journal.pone.0174231 Yousefpour R, Mohadjer MMR, Saghebtalebi K (2005). Study of oriental beech succession in Fandoghlu forest. Iranian Journal of Natural Resources 57 (4): 703-714. [In Persian]

Yousefzadeh H, Tabari M, Akbarinia M, Akbarian MR, Bussotti F (2010). Morphological plasticity of Parrotia persica leaves in eastern Hyrcanian forests (Iran) is related to altitude. Nordic Journal of Botany 28: 344-349. - doi: 10.1111/j.17561051.2009.00451.x

Zarafshar M, Akbarinia M, Bruschi P, Hosseiny SM, Yousefzade $H$, Taieby $M$, Sattarian A (2010). Phenotypic variation in chestnut (Castanea sativa Mill.) natural populations in Hyrcanian forest (north of Iran), revealed by leaf morphometric. Folia Oecologica 37: 105-113. [online] URL: http://ife.sk/wp-content/uploads/ 2016/10/FO_37_1_zarafshar.pdf

\section{Supplementary Material}

Tab. S1 - List of the leaf morphological traits analyzed in this study.

Link: Jahdi_3391@supploo1.pdf 